\title{
First record of the Mediterranean mussel Mytilus galloprovincialis (Bivalvia, Mytilidae) in Brazil
}

\author{
Carlos Eduardo Belz ${ }^{1,5}$; Luiz Ricardo L. Simone²; Nelson Silveira Júnior ${ }^{3}$; Rafael Antunes Baggio ${ }^{4}$; \\ Marcos de Vasconcellos Gernet ${ }^{1,6}$ \& Carlos João Birckolz ${ }^{1,7}$
}

\footnotetext{
1 Universidade Federal do Paraná (UFPR), Centro de Estudos do Mar (CEM), Laboratório de Ecologia Aplicada e Bioinvasões (LEBI0). Pontal do Paraná, PR, Brasil.

2 Universidade de São Paulo (USP), Museu de Zoologia (MZUSP). São Paulo, SP, Brasil. ORCID: http://orcid.org/0000-0002-1397-9823. E-mail: Irsimone@usp.br

${ }^{3}$ Nixxen Comercio de Frutos do Mar LTDA. Florianópolis, SC, Brasil. ORCID: http://orcid.org/0000-0001-8037-5141.E-mail: nelson.fazendamar@gmail.com

${ }^{4}$ Universidade Federal do Paraná (UFPR), Departamento de Zoologia (DZO0), Laboratório de Ecologia Molecular e Parasitologia Evolutiva (LEMPE). Curitiba, PR, Brasil. ORCID: http://orcid.org/0000-0001-8307-1426. E-mail: rbaggio@ufpr.br

${ }^{5}$ ORCID: http://orcid.org/0000-0002-2381-8185. E-mail: belzoceanos@gmail.com (corresponding author)

${ }^{6}$ ORCID: http://orcid.org/0000-0001-5116-5719. E-mail: Imv.gernet@gmail.com

7 ORCID: http://orcid.org/0000-0002-7896-1018. E-mail: carlosbirc@gmail.com
}

\begin{abstract}
The genus Mytilus comprises a large number of bivalve mollusk species distributed throughout the world and many of these species are considered invasive. In South America, many introductions of species of this genus have already taken place, including reports of hybridization between them. Now, the occurrence of the Mediterranean mussel Mytilus galloprovincialis is reported for the first time from the Brazilian coast. Several specimens of this mytilid were found in a shellfish growing areas in Florianópolis and Palhoça, Santa Catarina State, Brazil. Morphological analysis of the shells and molecular analysis through sequencing of the cytochrome oxidase subunit 1 ( $\mathrm{COI}$ ) confirmed the taxonomic identification. The species is known for its great invasive potential and can become a major environmental problem for seafood business and coastal communities, as it can compete and even hybridize with local species.
\end{abstract}

Key-Words. Mediterranean mussel; Mytilus galloprovincialis; Brazilian coast; First record; Santa Catarina.

\section{INTRODUCTION}

The Mytilidae Mytilus galloprovincialis (Lamarck, 1819) was originally described for the Mediterranean Sea, and later introduced in areas far from its region of origin. In the northern hemisphere, its presence has been confirmed in California (McDonald \& Koehn, 1988), Japan (Wilkins et al., 1983), Hong Kong (Lee \& Morton, 1985), China and Korea (McDonald et al., 1991). In the southern hemisphere, it occurs in South Africa (Grant \& Cherry, 1985) and is widely distributed throughout Australasia (McDonald et al., 1991). Its previous absence in South America was, for a long time, considered intriguing given the long history of trade between this continent and the countries bordering the Mediterranean (Seed, 1992). Later, then, the species began to be cited for South America, in Chile, Argentina and Uruguay (Seed, 1992; Daguin \& Borsa, 2000; Astorga et al., 2015;
GISD, 2019). It is a species with high capacity of invasion and with potential for competition and hybridization with native species (Lowe et al., 2000; Branch \& Steffani, 2004).

Species of the genus Mytilus are usually known as blue mussels. Its species mostly occur in temperate and cold regions of the world, and the different species have similar shells, so much that they are considered subspecies of the European M. edulis Linnaeus, 1758 by some authors. The shell similarity precludes easy detection of non-indigenous congener species (Astorga et al., 2015). In a South American example, a region that supposedly must have only the native M. platensis d'Orbigny, 1842, other two non-indigenous species were detected, M. edulis and M. galloprovincialis, in the Strait of Magellan (Oyarzún et al., 2016).

The aim of this work is to report for the first time the occurrence of the exotic species M. galloprovincialis in Brazilian coast. 


\section{MATERIAL AND METHODS}

\section{Study area and sampling}

Individuals of M. galloprovincialis (Fig. 1) were found associated with the cultures of the Mytilidae Perna perna (Linnaeus, 1758) from September 2016 to September 2018 in South Bay and in North Bay, between Santa Catarina Island (municipality of Florianópolis) and the continent (municipality of Palhoça), state of Santa Catarina, southern region of Brazil $\left(27^{\circ} 40^{\prime} \mathrm{S}, 48^{\circ} 35^{\prime} \mathrm{W}\right)$ (Fig. 2). Seeds and adults were observed adhered to the $P$. perna planting structures during the maricultural management. The specimens $(n=50)$ were collected in six points along the South Bay and one point in the North Bay and they are deposited in the malacological collection of the Museu de Zoologia da Universidade de São Paulo, São Paulo, Brazil (MZUSP 143542; MZUSP 143543) and in the malacological collection of the Laboratório de Ecologia Aplicada e Bioinvasões da Universidade Federal do Paraná, Pontal do Paraná, Brazil (LEBIO 543).

\section{Morphological and molecular identification}

Shell characters were used for initial identification (Poppe \& Goto, 1993; Sanjuan et al., 1994; Innes \& Bates, 1999; FAO, 2019) and the molecular analysis was performed through approximately a 650 bp sequence of the cytochrome oxidase subunit 1 (COI). DNA from adductor muscle of three samples was extract using the EZ-DNA kit (Biological Industries). The amplification was carried out in $25 \mu \mathrm{lPCR}$ with final concentrations of $2.5 x$ buffer, $3 \mathrm{mM}$ of $\mathrm{MgCl} 2,0.4 \mathrm{uM}$ of dNTP, 0.1 pmol of each HCO and LCO primer (Folmer et al., 1994), $0.1 \mathrm{U}$ of Taq Polymerase and $50 \mathrm{ng}$ of DNA template. Sequencing was performed with BigDye $^{\circledR}$ kit (Applied Biosystems) according to the manufacturer protocol. The sequencing product was purified with Sephadex G-50 (GE Healthcare) and sequenced with an ABi 3130 automatic sequencer (Applied Biosystems). The sequence was deposited in GenBank under the accession number MN615419.
Molecular identification was performed with three approaches. First, the barcode identification of each individual was performed in the BoldSystems v3 (Ratnasingham \& Hebert, 2007). Then, the barcode identification was confirmed by taxa similarity and phylogenetic analysis under Neighbor Joining (NJ) and Bayesian Inference (BI) approaches, respectively. Sequences of M. galloprovincialis and of close related species (i.e., Mytilus californianus Conrad, 1837, M. chilensis, M. coruscus Gould, 1861, M. edulis, M. platensis, M. trossulus Gould, 1850) accessed from GenBank (Table 1) were used as reference sequences. Sequences of $P$. perna were used to root the tree. The sequences were aligned using the online tool Guidance2 (Sela et al., 2015) with MAFFT version 7.123b algorithm (Katoh \& Standley, 2013). The substitution model (TrN93 + G, Tamura \& Nei, 1993) was selected with jModeltest 2.1.10 (Darriba et al., 2012). The NJ tree was constructed with Mega 7.0.26 (Kumar et al., 2016), and its robustness was assessed using 1,000 bootstrap replicates. The BI tree was constructed in Beast 1.8 (Drummond et al., 2012) with three independent runs of 50 million MCMC steps sampled each 5,000 trees (10\% of burn-in).

Table 1. Species and the GenBank accession number of the sequences used as reference for the molecular identification of the focal individual.

\begin{tabular}{ll}
\hline \multicolumn{1}{c}{ Species } & \multicolumn{1}{c}{ GenBank accession numbers } \\
\hline M. californianus & KF931702.1, KF931724.1, KF931745.1 \\
M. chilensis & KR066667.1, KR0666668.1, KR066669.1, KR066670.1, KR066677.1, \\
& KR066678.1, KR0666679.1, KR066680.1, KR066687.1, KR066756.1, \\
& KR066764.1 \\
M. coruscus & KC139326.1, KF154239.1, KM197995.1, MG214428.1 \\
M. edulis & AF241969.1, AY130053.1, EU915572.1, JF825556.1 \\
M. galloprovincialis & AB076943.1, AF241997.1, AY130054.1, AY130055.1, AY130056.1, \\
& AY130057.1, AY130058.1, AY130059.1, AY130060.1, AY497292.2, \\
& DQ917605.1, KP052906.1, KP052907.1, KP052908.1, KP052909.1, \\
& KP052910.1, KP052911.1, KP052912.1, KP052913.1, KP052914.1, \\
& KP052915.1, KP052916.1, KP052917.1, KP052918.1, KP052919.1, \\
& KP052920.1, KP052921.1, KP052922.1, KP052923.1, KP052924.1, \\
& KP052925.1, KP052926.1, KP052927.1 \\
M. platensis & KY454035.1, KY454034.1 \\
M. trossulus & AY130061.1, KF932117.1, KF932152.1, KF932224.1, KF932255.1, \\
& MF544912.1 \\
P. perna & DQ351427.1, DQ351453.1, DQ351475.1
\end{tabular}
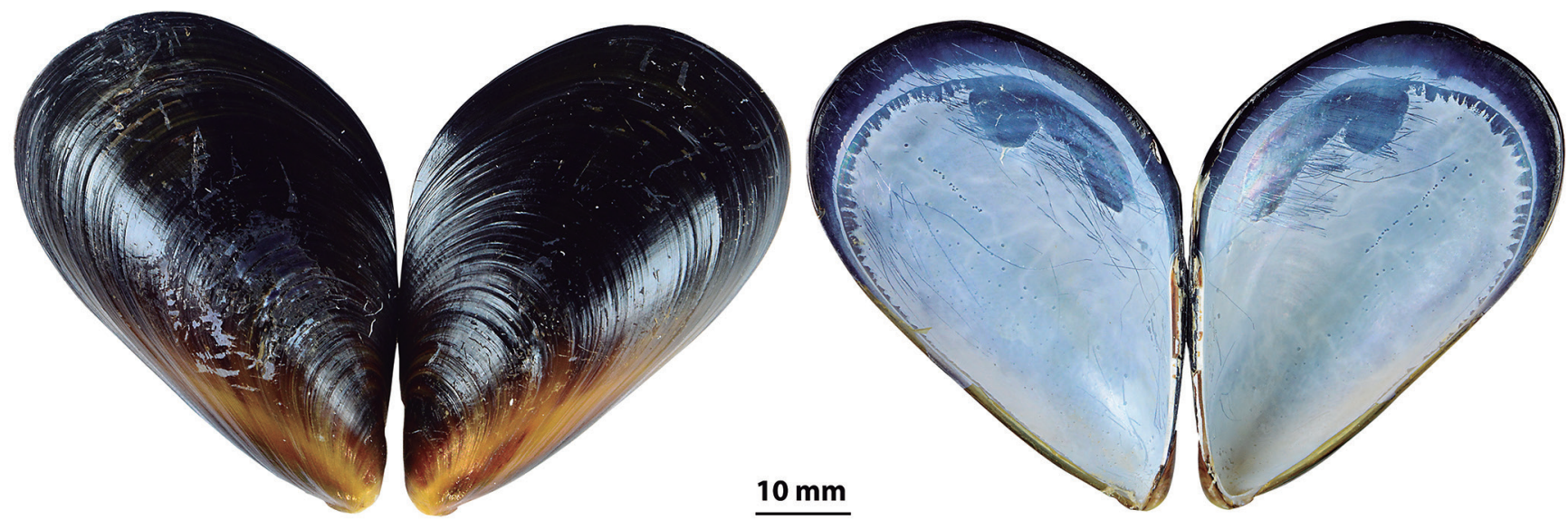

Figure 1. Shells of Mytilus galloprovincialis. Lot LEBI0 543. Shell length $=60 \mathrm{~mm}$. 


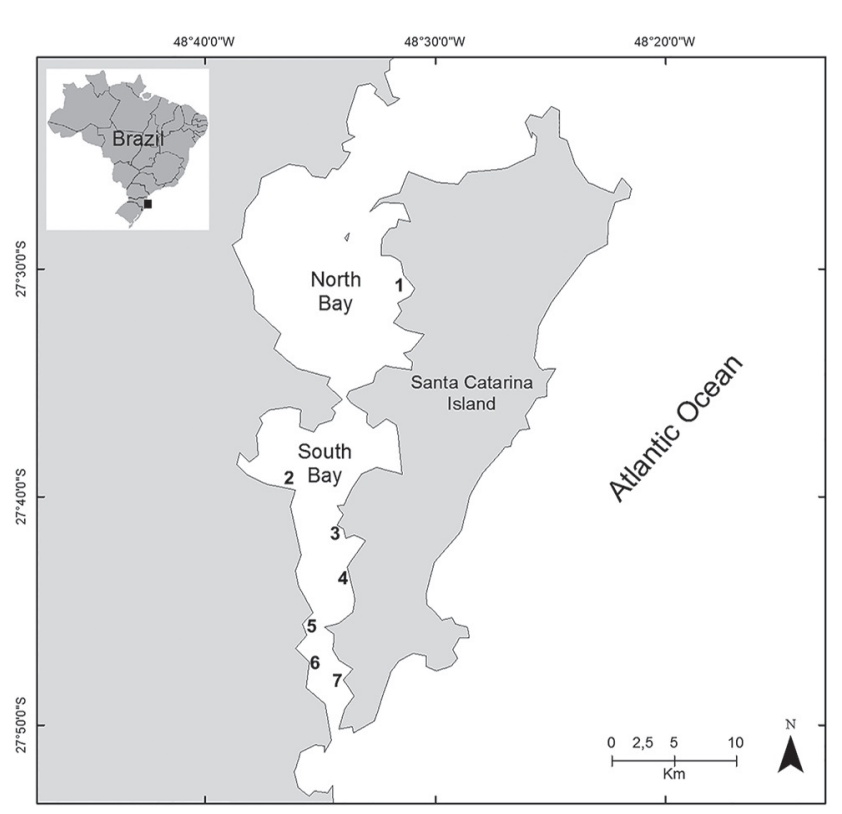

Figure 2. Sites of Perna perna planting where Mytilus galloprovincialis was found. (1) Santo Antônio de Lisboa, Florianópolis; (2) Ponta do Tomé, Palhoça; (3) Tapera, Florianópolis; (4) Costeira do Ribeirão, Florianópolis; (5) Ponta do Cedro, Palhoça; (6) Pedras Altas, Palhoça; (7) Caieira da Barra do Sul, Florianópolis.

\section{RESULTS}

Specimens were found associated to the cultivation of $P$. perna mussels during the management of cleaning and harvesting of bivalve production for commercialization. The first individuals were observed during spring 2016, but it was in spring 2017 that they began to cause concern among farmers, with higher density.

An internal small subumbonal white fold and a very dark color easily differentiate Mytilus spp. from the more common and planting cultivated $P$. perna. As the native species $M$. platensis has its northern boundary in Santa Catarina-Paraná region (Rios, 2009), a differentiation with M. galloprovincialis was necessary. Normally, M. platensis is smaller (up to $30 \mathrm{~mm}$ ), the valves are more elliptical, with ventral edge straight or convex (Rios, 2009). On the other hand, M. galloprovincialis easily reached $40 \mathrm{~mm}$, and usually has a more pointed anterior, umbonal region, with the ventral valves edge concave (FAO, 2019). The length of the individuals collected ranged from $45 \mathrm{~mm}$ to $83 \mathrm{~mm}$.

The molecular identification was coincident with the morphological identification of $M$. galloprovincialis. The

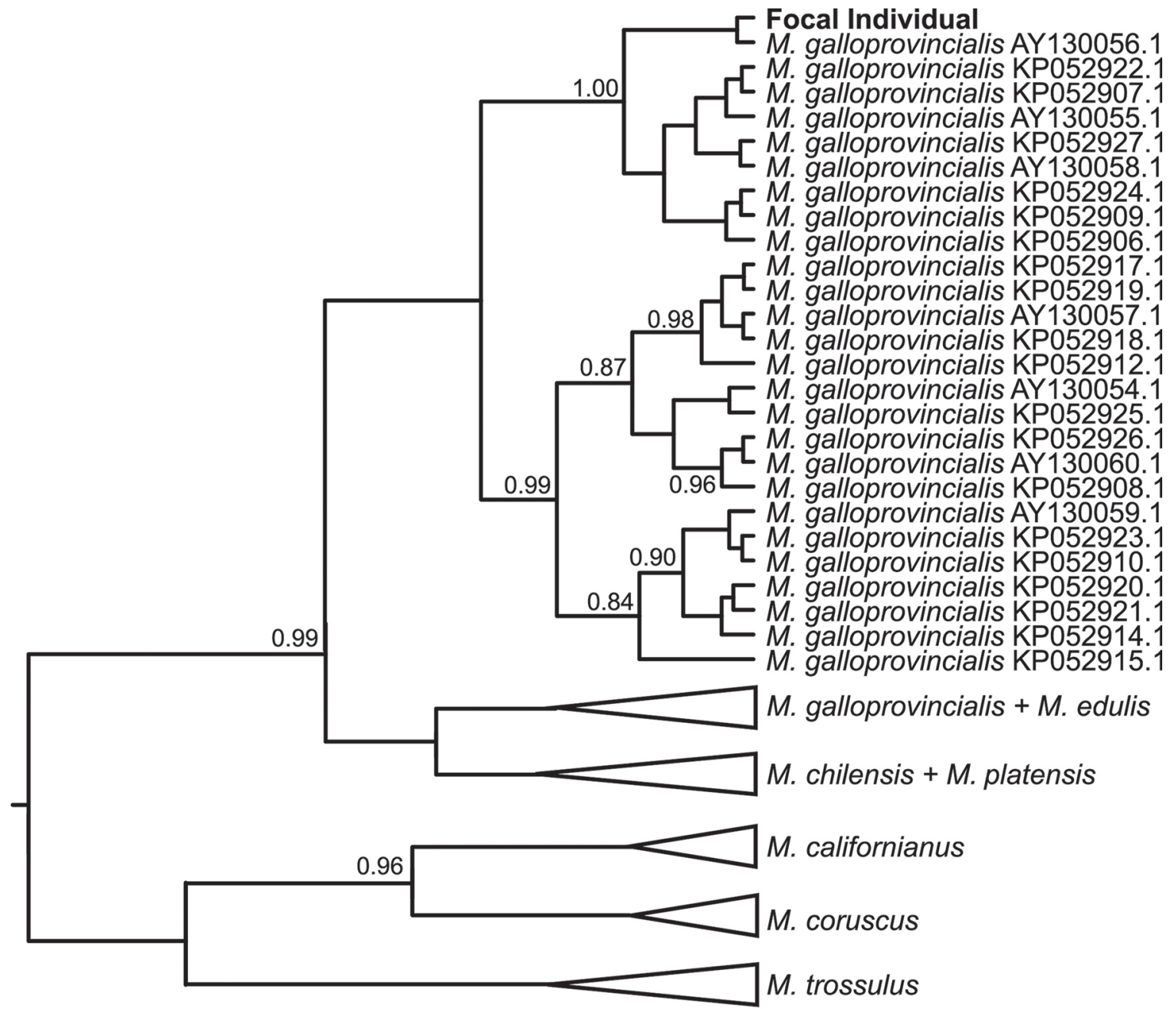

0.02

Figure 3. Genetic identification of the focal individual by phylogenetic analysis under Bayesian Inference (BI) based on COI mitochondrial gene. Only posterior probabilities higher than 0.75 are shown. Branch lengths represent units of substitutions per site. 
Brazilian samples presented between 99.5 and $97.6 \%$ of similarity with sequences of $M$. galloprovincialis available in the BoldSystems v3 database. Similarly, the BI (Fig. 3) and NJ (Fig. 4) trees assigned the Brazilian sample in the monophyletic groups of $M$. galloprovincialis with high branch support. These results indicate the occurrence of this invasive species in Brazilian coast.

In consecutive observations made during the spring of 2018, out of a total of 26 mussel ropes with an individual average weight of $15 \mathrm{~kg}$, occupying approximately 13 linear meters of cultivation, the average total weight was $366 \mathrm{~kg}$ of $P$. perna clean and ready for sale and $8.8 \mathrm{~kg}$ of M. galloprovincialis, or $2.4 \%$ of current production.

\section{DISCUSSION}

The interaction between P. perna and M. galloprovincialis has already been reported to the African coast, where the two species live together (Bownes \& McQuaid, 2006). However, hybridization cases such as those that occur on the Chilean coast can cause impact to other species (Valenzuela et al., 2016), as is the case in Venezuela with the introduction of another Mytilidae species [Perna viridis (Linnaeus, 1758)] in the early 1990s, and which has been competing strongly with the most abundant Mytilidae in the region (P. perna) (Rylander et al., 1996). Recently $P$. viridis was also introduced in Guanabara Bay, Rio de Janeiro, Brazil (Messano et al., 2019), which makes this scenario of frequent introductions of alien species and possible hybridizations increasingly worrying.

The introduction vector of M. galloprovincialis in Brazil is unknown, but Castro et al. (2017) indicate that ballast water, biofouling and aquaculture are the most common vectors of species introduction and propagation in the Atlantic Ocean.

The Santa Catarina region is today the largest producer of edible mollusks in Brazil, with 95\% of all production in the country (Suplicy et al., 2017). The results of this work show a $2.4 \%$ proportion of $M$. galloprovincialis in the cultivated areas studied. This is already a major economic impact because it reduces $P$. perna production. However, further studies should be conducted to identify other possible impacts, for only time will show whether this new introduction will become more of a cultivation possibility or more of a competitor of space and food with local species, compromising the production of $P$. perna.

In the last two centuries there has been an unprecedented increase in human influence on species exchange, leading to a homogenization of flora and fauna

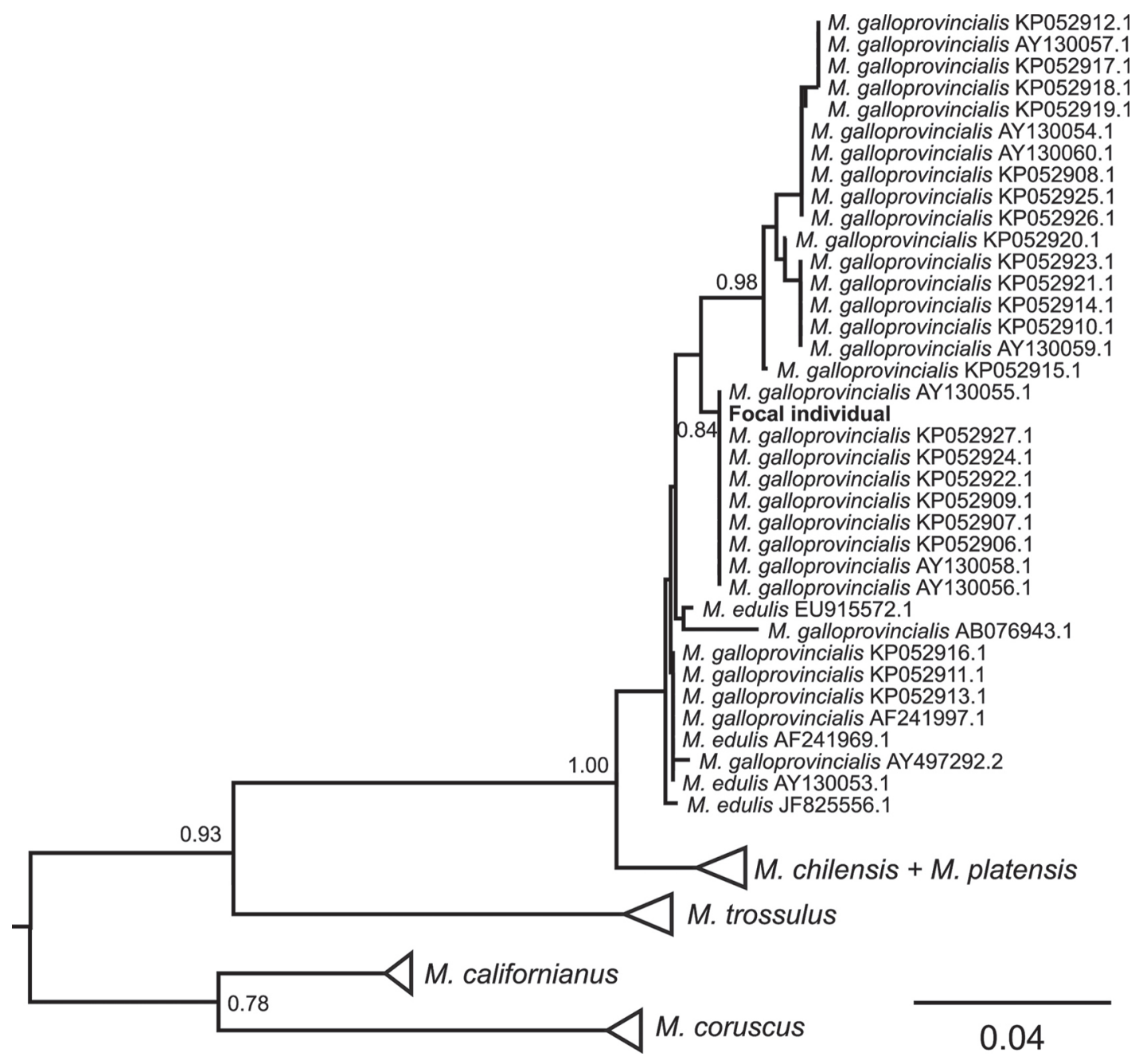

Figure 4. Genetic identification of the focal individual by similarity analysis under Neighbor-Joining (NJ) based on COI mitochondrial gene. Only bootstraps higher than 0.75 are shown. Branch lengths represent units of distance. 
and redefining species occurrence limits, affecting ecosystem functioning, human and animal health and economy (Seebens et al., 2017). This is particularly challenging in a megabiodiverse country like Brazil.

\section{ACKNOWLEDGMENTS}

We would like to thank two anonymous reviewers for their comments in the manuscript.

\section{REFERENCES}

Astorga, M.L.; Cardenas, L. \& Vargas, J. 2015. Phylogenetic approaches to delimit genetic lineages of the Mytilus complex of South America: how many species are there? Journal of Shellfish Research, 34(3): 919-930.

Bownes, S.J. \& McQuaid, C.D. 2006. Will the invasive mussel Mytilus galloprovincialis Lamarck replace the indigenous Perna perna $\mathrm{L}$. on the south coast of South Africa? Journal of Experimental Marine Biology and Ecology, 338(1): 140-151.

Branch, G.M. \& Steffani, C.N. 2004. Can we predict the effects of alien species? A case-history of the invasion of South Africa by Mytilus galloprovincialis (Lamarck). Journal of Experimental Marine Biology and Ecology, 300(1-2): 189-215.

Castro, M.C.T.; Fileman, T.W. \& Hall-Spencer, J.M. 2017. Invasive species in the Northeastern and Southwestern Atlantic Ocean: A review. Marine Pollution Bulletin, 116(1-2): 41-47.

Daguin, C. \& Borsa, P. 2000. Genetic relationships of Mytilus galloprovincialis Lmk. populations worldwide: evidence from nuclear - DNA markers. Geological Society of London, Special Publications, 177: 389-397.

Darriba, D.; Taboada, G.L.; Doallo, R. \& Posada, D. 2012. jModelTest 2: more models, new heuristics and parallel computing. Nature Methods, 9(8): 772

Drummond, A.J.; Suchard, M.A.; Xie, D. \& Rambaut, A. 2012. Bayesian phylogenetics with BEAUti and the BEAST 1.7. Molecular Biology and Evolution, 29(8): 1969-1973.

FA0 (Food and Agriculture Organization). 2019. Mytilus galloprovincialis (Lamarck, 1819). Available at:http://www.fao.org/fishery/species/3529/ en. Access in: 16/11/2019.

Folmer, 0.; Black, M.; Hoeh, W.; Lutz, R. \& Vrijenhoek, R. 1994. DNA primers for amplification of mitochondrial cytochrome $c$ oxidase subunit I from diverse metazoan invertebrates. Molecular Marine Biology and Biotechnology, 3(5): 294-299.

GISD (Global Invasive Species Database). 2019. Species profile: Mytilus galloprovincialis. Available at: http://www.iucngisd.org/gisd/species. php?sc=102. Access in: 12/08/2019.

Grant, W.S. \& Cherry, M.I. 1985. Mytilus galloprovincialis Lmk. in southern Africa. Journal of Experimental Marine Biology and Ecology, 90(2): 179-191.

Innes, J.D. \& Bates, J.A. 1999. Morphological variation of Mytilus edulis and Mytilus trossulus in eastern Newfoundland. Marine Biology, 133(4): 691-699.

Katoh, K. \& Standley, D.M. 2013. MAFFT multiple sequence alignment software version 7: improvements in performance and usability. Molecular Biology and Evolution, 30(4): 772-780.

Kumar, S.; Stecher, G. \& Tamura, K. 2016. MEGA7: Molecular Evolutionary Genetics Analysis version 7.0 for bigger datasets. Molecular Biology and Evolution, 33(7): 1870-1874.

Lee, S.Y. \& Morton, B.S. 1985. The introduction of the Mediterranean mussel Mytilus galloprovincialis into Hong Kong. Malacological Review, 18: 107-109.
Lowe, S.; Browne, M. \& Boudjelas, S. \& De Poorter, M. 2000. 100 of the world's worst invasive alien species: A selection from the Global Invasive Species Database. IUCN/Hollands Printing, Auckland.

McDonald, J.H. \& Koehn, R.K. 1988. The mussels Mytilus galloprovincialis and M. trossulus on the Pacific coast of North America. Marine Biology, 99(1): 111-118.

McDonald, J.H.; Seed, R. \& Koehn, R.K. 1991. Allozymes and morphometric characters of three species of Mytilus in the Northern and Southern Hemispheres. Marine Biology, 111(3): 323-333.

Messano, L.V.R.; Gonçalves, J.E.A.; Messano, H.F.; Campos, S.H.C. \& Coutinho, R. 2019. First report of the Asian green mussel Perna viridis (Linnaeus, 1758) in Rio de Janeiro, Brazil: a new record for the southern Atlantic Ocean. Biolnvasions Records, 8(3): 653-660.

Oyarzún, P.A.; Toro, J.E.; Cañete, J.I. \& Gardner, J.P.A. 2016. Bioinvasion threatens the genetic integrity of native diversity and a natural hybrid zone: smooth-shelled blue mussels (Mytilus spp.) in the Strait of Magellan. Biological Journal of the Linnean Society, 117(3): 574-585.

Poppe, G.T. \& Gotto, Y. 1993. European Seashells. Wiesbaden, Verlag Christa Hemmen. 221p.

Ratnasingham, S. \& Hebert, P.D.N. 2007. BOLD: The Barcode of Life Data System (www.barcodinglife.org). Molecular Ecology Notes, 7(3):355-364.

Rios, E.C. 2009. Compendium of Brazilian Sea Shells. Rio Grande, Evangraf. $668 \mathrm{p}$.

Rylander, K.; Pérez, J. \& Gómez, J. 1996. The distribution of the brown mussel Perna perna and the green mussel Perna viridis (Mollusca: Bivalvia: Mytilidae) in northeast Venezuela. Caribbean Marine Studies, 5: 86-87.

Sanjuan, A.; Zapata, C. \& Alvarez, G. 1994. Mytilus galloprovincialis and M. edulis on the coasts of Iberian Peninsula. Marine Ecology Progress Series, 113(1): 131-146.

Seebens, H.; Blackburn, T.M.; Dyer, E.E.; Genovesi, P.; Hulme, P.E.; Jeschke, J.M.; Pagad, S.; Pysek, P.; Winter, M.; Arianoutsou, M.; Bacher, S.; Blasius, B.; Brundu, G.; Capinha, C.; Celesti-Grapow, L.; Dawson, W.; Dullinger, S.; Fuentes, N.; Jäger, H.; Kartesz, J.; Kenis, M.; Kreft, H.; Kühn, I.; Lenzner, B.; Liebhold, A.; Mosena, A.; Moser, D.; Nishino, M.; Pearman, D.; Pergl, J.; Rabitsch, W.; Rojas-Sandoval, J.; Roques, A.; Rorke, S.; Rossinelli, S.; Roy, HE.; Scalera R.; Schindler, S.; Tajerova K.S.; Tokarska-Guzik B.; van Kleunen, M.; Walker, K.; Weigelt, P.; Yamanaka, T. \& Ess, F. 2017. No saturation in the accumulation of alien species worldwide. Nature Communications, 8: 14435.

Seed, R. 1992. Systematic evolution and distribution of mussels belonging to the genus Mytilus: An overview. American Malacological Bulletin, 9(2): 123-137.

Sela, I.; Ashkenazy, H.; Katoh, K. \& Pupko, T. 2015. GUIDANCE2: accurate detection of unreliable alignment regions accounting for the uncertainty of multiple parameters. Nucleic Acids Research, 43(W1):W7-W14.

Suplicy, F.M.; Vianna, L.F.N.; Rupp, G.S.; Novaes, A.L.T.; Garbossa, L.H.P.; Souza, R.V.S.; Guzenski, J.; Costa, S.W.; Silva, F.M. \& Santos, A.A. 2017. Planning and management for sustainable coastal aquaculture development in Santa Catarina State, south Brazil. Reviews in Aquaculture, 9(2): 107-124.

Tamura, K. \& Nei, M. 1993. Estimation of the number of nucleotide substitution in the control region of mitochondrial DNA in humans and chimpanzees. Molecular Biology and Evolution, 10(3): 512-526.

Valenzuela, A.; Astorga, M.P.; Oyarzún, P.A. \& Toro, J.E. 2016. Caracterización genética de híbridos entre las especies Mytilus edulis platensis y Mytilus galloprovincialis (Mytilidae: Bivalvia) en la costa chilena. Latin American Journal of Aquatic Research, 44(1): 171-176.

Wilkins, N.P.; Fujino, K. \& Gosling, E.M. 1983. The Mediterranean mussel Mytilus galloprovincialis Lmk. in Japan. Biological Journal of the Linnean Society, 20(4): 365-374. 